\title{
Responses of Birds, Rodents, and Vegetation to Livestock Exclosure in a Semidesert Grass- land Site
}

\author{
CARL E. BOCK, JANE H. BOCK, WILLIAM R. KENNEY, AND VERNON M. HAWTHORNE
}

\section{Abstract}

Livestock have been excluded from a 3,160-ha range in southeastern Arizona since 1968. Compared to an adjacent continuously grazed area, in 1981-82 a protected upland site supported $45 \%$ more grass cover, a comparatively heterogeneous grass community, and 4 times as many shrubs. Grama grasses (Bouteloua spp.) were equally common in and outside the exclosure, while a variety of other species, especially plains lovegrass (Eragrostis intermedia) and Arizona cottontop (Trichachne californicum) were much more abundant on the protected site. The grazed area supported significantly higher numbers of birds in summer, while densities did not differ in winter. Rodents were significantly more abundant inside the protected area. Species of birds and rodents more common in the grazed area included those typical of more xeric lowland habitats and those preferring open ground for feeding. Species more common on the protected site were those which characterize semidesert or plains grasslands, and which prefer substantial grass or shrub cover. Grazing appeared to favor birds as a class over rodents.

Livestock exclosures have potential value in assessing the effects of grazing upon vegetation and wildlife (e.g., Turner et al. 1980). However, most protected sites are too small for meaningful evalution of grazing impacts on birds and mammals. The AppletonWhittel Research Ranch is a large $(3,160$ ha) National Audubon Society preserve in southeastern Arizona, protected from livestock grazing since 1968. In 1981-82, we compared vegetation, bird, and rodent populations between the exclosure and a moderately grazed but otherwise similar and adjacent grama grass-shrubland site.

\section{Study Area and Methods}

The study area lies at about $1,500 \mathrm{~m}$ elevation in Santa Cruz County, Ariz. Temperatures range from a mean January minimum of $-1.7^{\circ} \mathrm{C}$ to a mean June maximum of $32.4^{\circ} \mathrm{C}$. Average annual precipitation in this semidesert grassland is $43 \mathrm{~cm}$, with about half occurring in July and August.

The site sampled was a 300-ha mesa extending from the exclosure across a boundary fence onto an adjacent cattle ranch. This was the only topographically uniform area large enough to permit meaningful comparison of bird and rodent populations, where we could be confident that the differences across the fenceline were due entirely to effects of livestock grazing. Slopes were $<5 \%$ throughout, and soils a uniform gravelly loam of the White House series (Richardson et al. 1979). Livestock density on the grazed pasture just prior to and during data collection was approximately 1 cow per 10 ha. Grazing levels doubtless were much higher historically, both on and off the exclosure (Bahre 1977), but stocking data are unavailable.

Two grazed and two ungrazed bird census plots $(50 \times 500-\mathrm{m})$

Authors are at the Appleton-Whittell Research Ranch, P.O. Box 44, Elgin, Ariz. 85611, and Department of Environmental, Population, and Organismic Biology. University of Colorado, Boulder 80309.

This study was supported by Earthwatch and the Center for Field Research, by the University of Colorado Council on Research and Creative Work, and by the National Audubon Society. We thank D. Armstrong, M. Holmgren, B. Johnston, P. Sanchini, B. Webb, and 23 Earthwatch volunteers for advice and field assistance. Mr. William Brophy kindly allowed access to the Babocomari Ranch.

Manuscript received February 16, 1983 were established perpendicular to the boundary fence. These were located to avoid mesa edges and ravines, but to be at the maximum possible lateral distance from one another (about $400 \mathrm{~m}$ ). Teams of 6-8 observers walked abreast through the plots, counting and identifying individual birds flushed from them. It is unlikely that many birds escaped detection, since inter-observer distance was only 7-8 m, and the habitat was open and low in profile. Plots were sampled no more than once per day, in early mornings of clear and relatively calm days. Each count required about $30 \mathrm{~min}$. Counts were made from late July to early August of 1981 and 1982 (11 counts $/$ plot $=11$ hours total census time per treatment); winter counts were made in January of 1982 and 1983 ( 16 counts $/$ plot $=16$ hours total census time per treatment). Total numbers of sightings were compared within-season between the grazed and ungrazed areas using the chi-square statistic.

Two 600-m lines of Sherman live-traps were located centrally on the mesa and perpendicular to the fenceline, one in grazed and one

Table 1. Ground cover, expressed as percent of points on line transects, in grazed vs. ungrazed semidesert grassland in southenstern Arizona (n = 800 points per treatment). Chi-square values were calculated using actual numbers of points. Species shown are those comprising $\geq 1 \%$ cover on at least one site.

\begin{tabular}{lccc}
\hline & \multicolumn{2}{c}{ Percent ground cover } & \\
\cline { 2 - 3 } Category & Grazed & Ungrazed & Chi-square \\
\hline Grasses - total & 55.6 & $80.4^{* *}$ & 36.03 \\
Andropogon barbinodis & 1.3 & 1.3 & 0 \\
Aristida glauca & 0.3 & 1.0 & 3.60 \\
A. purpurea & 2.1 & $7.4^{* *}$ & 23.21 \\
A. ternipes & 2.5 & $4.6^{*}$ & 5.07 \\
Bouteloua chondrosioides & $3.1^{*}$ & 1.5 & 4.56 \\
B. curtipendula & 15.6 & 14.0 & 0.71 \\
B. hirsutum & 4.5 & 3.5 & 1.00 \\
B. gracilis & 20.1 & 22.0 & 0.67 \\
Eragrostis intermedia & 0 & $6.1^{* *}$ & 49.00 \\
Hilaria belangeri & $2.0^{*}$ & 0.4 & 8.89 \\
Lycurus phleoides & 2.4 & $8.1^{*}$ & 25.19 \\
Panicum obtusum & 0.6 & $3.6^{* *}$ & 16.94 \\
Trichachne californicum & 0.1 & $4.3^{*}$ & 31.11 \\
& & & \\
Herbs - total & 5.6 & $12.0^{* *}$ & 18.45 \\
Convolvulus incanus & 0.5 & 1.4 & 3.26 \\
Croton corymbulosus & 2.0 & 3.5 & 3.27 \\
Erigeran nudiflarus & 1.1 & 1.3 & 0.05 \\
Evolvulus sericeus & 0.1 & $1.6^{*}$ & 10.29 \\
Woody plants - total & 11.5 & 13.5 & 1.28 \\
Baccharis pteronioides & 1.0 & 2.0 & 2.67 \\
Desmanthus cooleyi & 3.6 & $6.0^{*}$ & 5.13 \\
Haplopappus nuttallii & 1.9 & 1.0 & 2.13 \\
Malvastrum bicuspidatum & 3.3 & 3.0 & 0.08 \\
Bare ground & $34.6 * *$ & 17.6 & 44.25 \\
\hline & & & \\
\hline
\end{tabular}

*Significantly greater than other treatment $(\boldsymbol{P}<.05)$.

* Significantly greater than other treatment $(P<001)$ 
Tahle 2. Numbers and sizes of larger woody plant species in grazed vs. ungrazed semidesert grassland. Plots were $200 \mathrm{~m}$ ( $\mathrm{n}=25 /$ treatment). Up to 5 plants of each species were measured for maximum height and crown diameter on each plot.

\begin{tabular}{|c|c|c|c|c|c|c|c|c|c|}
\hline \multirow[b]{2}{*}{ Species } & \multirow[b]{2}{*}{ Treatment } & \multicolumn{2}{|c|}{ Individuals/plot } & \multicolumn{3}{|c|}{ Maximum height $(\mathrm{cm})$} & \multicolumn{3}{|c|}{ Maximum width (cm) } \\
\hline & & $\bar{X}(\mathrm{SD})$ & $t$ & $\bar{X}(\mathrm{SD})$ & $\overline{\mathbf{n}}$ & & $\bar{X}(\mathrm{SD})$ & $\bar{n}$ & $t$ \\
\hline Chrysothamnus nauseosus & $\begin{array}{l}\text { Grazed } \\
\text { Ungrazed }\end{array}$ & $\begin{array}{c}0.6(2.1) \\
14.8(11.7)\end{array}$ & $5.97 * *$ & $\begin{array}{l}37.1(8.1) \\
42.6(10.4)\end{array}$ & $\begin{array}{l}14 \\
76\end{array}$ & 1.87 & $\begin{array}{l}28.2(19.4) \\
24.6(10.3)\end{array}$ & $\begin{array}{l}14 \\
76\end{array}$ & 1.22 \\
\hline Baccharis pteronioides & $\begin{array}{l}\text { Grazed } \\
\text { Ungrazed }\end{array}$ & $\begin{array}{r}5.9(5.8) \\
18.2(8.4)\end{array}$ & $6.02 * *$ & $\begin{array}{l}50.8(12.0) \\
69.7(13.1)\end{array}$ & $\begin{array}{l}58 \\
99\end{array}$ & $9.57^{* *}$ & $\begin{array}{r}74.4(29.4) \\
103.4(31.8)\end{array}$ & $\begin{array}{l}58 \\
99\end{array}$ & $6.01 *$ \\
\hline Haplopappus tenuisectus & $\begin{array}{l}\text { Grazed } \\
\text { Ungrazed }\end{array}$ & $\begin{array}{l}2.2(5.1) \\
3.0(4.3)\end{array}$ & 0.60 & $\begin{array}{l}34.1(13.0) \\
41.8(14.6)\end{array}$ & $\begin{array}{l}30 \\
30\end{array}$ & $2.16^{*}$ & $\begin{array}{l}36.8(24.0) \\
50.9(26.2)\end{array}$ & $\begin{array}{l}30 \\
30\end{array}$ & $2.17^{*}$ \\
\hline Prosopis juliflora & $\begin{array}{l}\text { Grazed } \\
\text { Ungrazed }\end{array}$ & $\begin{array}{l}0.5(0.8) \\
0.4(0.6)\end{array}$ & 0.50 & $\begin{array}{l}233.3(107.4) \\
205.4(62.8)\end{array}$ & $\begin{array}{l}25 \\
25\end{array}$ & 1.12 & $\begin{array}{l}333.2(132.8) \\
292.7(87.1)\end{array}$ & $\begin{array}{l}25 \\
25\end{array}$ & 1.28 \\
\hline Senecio douglasii & $\begin{array}{l}\text { Grazed } \\
\text { Ungrazed }\end{array}$ & $\begin{array}{ll}0.3 & (0.5) \\
1.2 & (2.4)\end{array}$ & 1.83 & $\begin{array}{l}49.7(9.1) \\
79.1(12.2)\end{array}$ & $\begin{array}{l}11 \\
29\end{array}$ & $7.24 * *$ & $\begin{array}{l}43.7(22.1) \\
60.7(16.9)\end{array}$ & $\begin{array}{l}11 \\
29\end{array}$ & $2.62^{*}$ \\
\hline Total woody plants & $\begin{array}{l}\text { Grazed } \\
\text { Ungrazed }\end{array}$ & $\begin{array}{r}9.5(7.0) \\
37.6(15.6)\end{array}$ & $8.22 * *$ & & & & & & \\
\hline
\end{tabular}

* Significantly greater on ungrazed plots $(P<0.05)$

** Significantly greater on ungrazed plots $(P<0.001)$.

in ungrazed habitat. Each line included 60 traps, set in pairs at 20-m intervals. Traps were baited with rolled oats, opened two hours before sunset and closed two hours after sunrise the follow- ing mornings, after captured animals were identified and released. Sampling was conducted on 71 days between July 1981 and January 1983, and total captures/treatment compared with the chisquare statistic.

Table 3. Total numbers of birds flushed off $50 \times 500$-m plots in grazed vs. ungrazed semidesert grassland in southeastern Arizona. Data were collected in late July - early August of 1981 and 1982, and in January of 1982 and 1983 . Sampling effort = 22 counts per treatment in summer, 32 counts/treatment in winter.

\begin{tabular}{|c|c|c|c|c|c|c|}
\hline \multirow[b]{3}{*}{ Species } & \multicolumn{6}{|c|}{ Numbers per treatment } \\
\hline & \multicolumn{3}{|c|}{ Summer } & \multicolumn{3}{|c|}{ Winter } \\
\hline & Grazed & Ungrazed & Chi-square & Grazed & Ungrazed & Chi-square \\
\hline $\begin{array}{l}\text { Scaled quail } \\
\text { (Callipepla squamata) }\end{array}$ & $48^{* *}$ & 5 & & 34.89 & & \\
\hline $\begin{array}{l}\text { Mourning dove } \\
\text { (Zenaida macroura) }\end{array}$ & $20^{*}$ & 7 & 6.26 & & & \\
\hline $\begin{array}{l}\text { Northern flicker } \\
\text { (Colaptes auratus) }\end{array}$ & $5^{*}$ & 0 & 5.00 & & & \\
\hline $\begin{array}{l}\text { Cassin's kingbird } \\
\text { (Tyrannus vociferans) }\end{array}$ & 8 & 3 & 2.27 & & & \\
\hline $\begin{array}{l}\text { Western kingbird } \\
\text { (Tyrannus verticalis) }\end{array}$ & 2 & 1 & 0.33 & & & \\
\hline $\begin{array}{l}\text { Horned lark } \\
\quad \text { (Eremophila alpestris) }\end{array}$ & $101^{* *}$ & 24 & 47.43 & 6 & 3 & 1.00 \\
\hline $\begin{array}{l}\text { Northern mockingbird } \\
\text { (Mimus polyglottos) }\end{array}$ & $22^{*}$ & 9 & 5.45 & & & \\
\hline $\begin{array}{l}\text { Loggerhead shrike } \\
\text { (Lanius ludovicianus) }\end{array}$ & 2 & 4 & 0.67 & 0 & 2 & 2.00 \\
\hline $\begin{array}{l}\text { Blue grosbeak } \\
\text { (Guiraca caerulea) }\end{array}$ & 2 & 2 & $\mathbf{0}$ & & & \\
\hline $\begin{array}{l}\text { Cassin's sparrow } \\
\text { (Aimophila cassinii) }\end{array}$ & 0 & $66^{* *}$ & 66.00 & 0 & $42^{* *}$ & 42.00 \\
\hline $\begin{array}{l}\text { Chipping sparrow } \\
\text { (Spizella passerina) }\end{array}$ & & & & 7 & $21^{*}$ & 7.00 \\
\hline $\begin{array}{l}\text { Brewer's sparrow } \\
\text { (Spizella breweri) }\end{array}$ & & & & $82 * *$ & 4 & 70.74 \\
\hline $\begin{array}{l}\text { Vesper sparrow } \\
\quad \text { (Pooecetes gramineus) }\end{array}$ & & & & 103 & 90 & 0.88 \\
\hline $\begin{array}{l}\text { Black-throated sparrow } \\
\text { (Amphispiza bilineata) }\end{array}$ & 2 & 2 & $\mathbf{0}$ & $19^{* *}$ & 0 & 19.00 \\
\hline $\begin{array}{l}\text { Lark sparrow } \\
\text { (Chondestes grammacus) }\end{array}$ & $40^{* *}$ & 4 & 29.45 & & & \\
\hline $\begin{array}{l}\text { Grasshopper sparrow } \\
\text { (Ammodramus savannarum) }\end{array}$ & 0 & $53^{* *}$ & 53.00 & 13 & $65^{* *}$ & 34.67 \\
\hline $\begin{array}{l}\text { Eastern meadowlark } \\
\text { (Sturnella magna) }\end{array}$ & 18 & 13 & 0.81 & 17 & 15 & 0.13 \\
\hline Total birds counted & $270^{*}$ & 193 & 12.81 & 247 & 242 & 0.05 \\
\hline
\end{tabular}

*Significantly greater than other treatment $(P<0.05)$.

** Significantly greater than other treatment $(P<0.001)$.

'Despite range maps in some bird books, the eastern meadowlard does summer in Arizona (Phillips et al. 1964) and definitely is the one identified on the study site. 
Four $200-\mathrm{m}$ vegetation line transects were located coincident with the edges of the bird sampling plots. At $0.5-\mathrm{m}$ intervals we recorded at each point: (1) presence, by basal area, of all species of grasses and herbs, (2) presence, by canopy, of all trees and shrubs, or (3) presence of bare ground or litter in the absence of live vegetation. Data were collected in July-August 1981 ( $n=800$ points/treatment), and results compared with the chi-square statistic. Densities and sizes of larger woody plants were measured in January 1982 on $25200-\mathrm{m}^{2}$ plots per treatment, spaced uniformly across the mesa parallel to the boundary fence. We measured the maximum height and maximum width (crown diameter) for the first 5 individuals of each woody species counted in each $200-\mathrm{m}^{2}$ plot. Sample sizes thus varied depending upon shrub densities. $F$-tests were used to test for equality of variances, and $t$ or approximate $t$-tests applied accordingly (Sokal and Rohlf 1981), to compare mean woody plant densities and sizes betwen treatments. Botanical nomenclature is from Kearney and Peebles (1969).

\section{Results}

The livestock exclosure supported $45 \%$ more grass cover, a comparatively heterogeneous grass community, and significantly more herb cover than the grazed pasture (Table 1). Woody plants were significantly more abundant overall, and various individual shrub species were denser and/or larger on the protected site (Table 2). Mesquite trees (Prosopis juliflora) were not common in the study area, and did not differ between treatments. The shrubs yerba de pasmo (Baccharis pteronioides), burro weed (Haplopappus tenuisectus), and groundsel (Senecio douglasii), which were significantly larger in the exclosure, all showed evidence of cattle browsing outside the protected area.

Total bird numbers were higher on the grazed than on the ungrazed plots in summer, while overall numbers did not differ in winter (Table 3). Raptorial birds rarely were seen and were not included in the analysis. In summer, 6 bird species were significantly more abundant in the grazed pasture, while 2 species were more common in the protected area. Two wintering species were significantly more common in the grazed area, while 3 species were more abundant in the exclosure.

Ground squirrels were rare or absent from the study site, so our largely nocturnal trapping effort almost certainly provided a meaningful comparison of total rodent numbers on both treatments. The spotted ground squirrel (Spermophilus spilosoma) and rock squirrel ( $S$. variegatus) do occur on the Research Ranch, but we did not trap either during the 71 mornings and late afternoons when the traps were open. Furthermore, we never observed either species during the bird counts or vegetation sampling. Similarly, jackrabbits and cottontail rabbits were rare on the mesa sampled, although the latter was quite common on bottomland sites. Total rodents were significantly more abundant on the exclosure (Table 4). Five species were trapped significantly more often on the protected site, while only the Merriam kangaroo rat clearly preferred the grazed pasture.

\section{Discussion}

No data were taken on our study site prior to livestock removal. However, Bonham (1972) conducted a general vegetation survey of the Research Ranch in 1970-71, and found a total grass cover of about $40 \%$ for associations similar to our study area. This figure is closer to that on our grazed site, as measured in 1981, and less than half the amount we found on the exclosure (Table 1). It appears that vegetation changes on the exclosure have been dramatic.

Grass cover in 1981 was 1.4 times higher on the protected area (Table 1). However, blue grama (Bouteloua gracilis) and sideoats grama (B. curtipendula) were the most common grasses on both sites and did not differ significantly between them. Various other perennial grasses, especially threeawn (Aristida spp.), plains lovegrass (Eragrosis intermedia), Arizona cottontop (Trichachne cali- fornicum), wolftail (Lycurus phleoides), and vine mesquite (Panicum obtusum), were much more abundant on the exclosure. The grama species, perhaps because of their co-evolution with large native ungulates (Mack and Thompson 1982), appear to form a sort of grazing-resistant matrix, into which other species have invaded in the absence of livestock.

Various studies have shown that livestock exclusion does not retard and may even accelerate woody plant growth in Southwestern rangelands (e.g., Smith and Schumutz 1975, Chew 1982). Results of the present study strongly support this conclusion (Table 2). Historical overgrazing may set in motion patterns of shrub invasion which then continue on their own, at least for some time, regardless of subsequent land management practices.

Rodents and birds differed dramatically between grazed and ungrazed habitats (Tables 3 and 4). Two major trends are apparent in our data. First, several of the species more abundant in the grazed area are typical of lower elevations and more xeric habitats. These included the scaled quail (Johnsgard 1973), the Brewer's and black-throated sparrows (Phillips et al. 1964), and the Merriam kangaroo rat (Rozenzwieg and Winakur 1969). These species may be valuable indicators of desertification of semidesert and plains grassland ecosystems.

Table 4. Total numbers of rodents captured in 71 trapline-nights (60 traps per treatment) on a grazed vs. ungrazed semidesert grassland site between July 1981 and January 1983.

\begin{tabular}{|c|c|c|c|}
\hline \multirow[b]{2}{*}{ Species } & \multicolumn{2}{|c|}{ Total captures } & \multirow[b]{2}{*}{ Chi-square } \\
\hline & Grazed & Ungrazed & \\
\hline $\begin{array}{l}\text { Silky pocket mouse } \\
\text { (Perognathus flavus) }\end{array}$ & 5 & 8 & 0.69 \\
\hline $\begin{array}{l}\text { Hispid pockct mouse } \\
\text { (Perognathus hispidus) }\end{array}$ & 16 & $38^{*}$ & 8.96 \\
\hline $\begin{array}{l}\text { Merriam kangaroo rat } \\
\text { (Dipodomys merriami) }\end{array}$ & $92 * *$ & 5 & 78.03 \\
\hline $\begin{array}{l}\text { Western harvest mouse } \\
\text { (Reithrodontomys megalotis }\end{array}$ & 4 & $26^{*}$ & 16.13 \\
\hline $\begin{array}{l}\text { Deer mouse } \\
\text { (Peromyscus maniculatus) }\end{array}$ & 130 & 146 & 0.93 \\
\hline $\begin{array}{l}\text { White-footed mouse } \\
\text { (Peromyscus leucopus) }\end{array}$ & 24 & $45^{*}$ & 6.39 \\
\hline $\begin{array}{l}\text { Southern grasshopper mouse } \\
\text { (Onychomys torridus) }\end{array}$ & 8 & $42^{*}$ & 23.12 \\
\hline $\begin{array}{l}\text { Hispid cotton rat } \\
\text { (Sigmodon hispidus) }\end{array}$ & 49 & $118^{* *}$ & 28.50 \\
\hline Total rodents & 328 & $428 * *$ & 13.23 \\
\hline
\end{tabular}

*Significantly greater than other treatment $(P<0.05)$.

** Significantly greater than other treatment $(P<0.001)$.

Second, amount of ground and shrub cover was the major determinant of the 2 animal communities. Grasshopper and Cassin's sparrows prefer substantial grass and shrub cover (Wiens 1973, Hubbard 1977). These were the most abundant summer birds in the ungrazed area, yet we failed to record a single individual of either species using the adjacent grazed pasture. Mourning doves, horned larks, lark sparrows, and mockingbirds are open-ground foragers (Laskey 1962, Baepler 1968, Leopold 1972, Cannings and Threllfall 1981), and all were more abundant on the grazed site. Among the common rodents, only the deermouse occupied both sites in equal abundance. This is one of the most widespread and generalized of all North American rodents (Baker 1968). The hispid pocket mouse, white-footed mouse, western harvest mouse, and hispid cotton rat all were more abundant on the protected range, and all have been shown to prefer or characterize areas with substantial shrub and/or ground cover (Baker 1968, Rosenzweig and Winakur 1969, Cameron and Spencer 1981, Webster and Jones 1982). 
Collectively, grazing appeared to favor birds over rodents. Rodents, because of their superior olfactory abilities, probably are better adapted to locate food in areas of dense cover. The mobility and visual orientation of birds would adapt them better as a group to avoid aerial predators in the open, and to forage in sites with patchily distributed food resources, and where food and cover may be physically separated.

\section{Literature Cited}

Baepler, D.H. 1968. Lark sparrow. p. 886-902. In: Life histories of North American cardinals, grosbeaks, buntings, towhees, finches, sparrows, and allies. A.C. Bent (ed.), U.S. Nat. Mus. Bull. 237.

Bahre, C.J. 1977. Land-use history of the Research Ranch, Elgin, Arizona. J. Ariz. Acad. Sci. 12:1-32.

Baker, R.H. 1968. Habitats and distribution. p. 98-126. In: Biology of Peromyscus. J.A. King (ed.), Amer. Soc. Mammal., Spec. Pub. No. 2.

Bonham, C.D. 1972. Ecological inventory and data storage retrieval system for the Research Ranch. Colorado State Univ., Range Sci. Dep. Sci. Ser. No. 14.

Cameron, G.N., and S.R. Spencer. 1981. Sigmodon hispidus. Mammalian species, No. 158, Amer. Soc. Mammal.

Connings, R.J., and W. Threlfall. 1981. Horned lark breeding biology at Cape St. Marys, Newfoundland. Wilson Bull. 93:519-530.

Chew, R.M. 1982. Changes in herbaceous and suffrutescent perennials in grazed and ungrazed desertified grassland in southeastern Arizona, 1958-1978. Amer. Midl. Natur. 108:159-169.

Hubbard, J.P. 1977. The status of Cassin's sparrow in New Mexico and adjacent states. Amer. Birds 31:933-941.
Johnsgard, P.A. 1973. Grouse and quails of North America. Univ. Nebraska Press, Lincoln.

Keamey, T.H., and R.H. Peebles. 1969. Arizona flora. Univ. California Press, Berkeley.

Laskey, A.R. 1962. Breeding biology of mockingbirds. Auk 79:86-96.

Leopold, A.S. 1972. The wildlife of Mexico. Univ. California Press, Berkeley.

Mack, R.N., and J.N. Thompson. 1982. Evolution in steppe with few large, hooved mammals. Amer. Natur. 119:757-773.

Phillips, A., J. Marshall, and G. Monson. 1964. The birds of Arizona. Univ. Arizona Press, Tucson.

Richardson, M.L., S.D. Clemmons, and J.C. Walker. 1979. Soil survey of Santa Cruz and parts of Cochise and Pima Counties, Arizona. U.S. Dep. Agr., Washington, D.C.

Rosenzweig, M.L., and J. Winakur. 1969. Population ecology of desert rodent communities: habitats and environmental complexity. Ecology 50:558-572.

Smith, D.A., and E.M. Schmutz. 1975. Vegetative changes on protected versus grazed desert grassland ranges in Arizona. J. Range Manage. 28:453-458.

Sokal, R.R., and F.J. Rohlf. 1981. Biometry (2nd ed.). W.H. Freeman and Co., San Francisco, Calif.

Turner, R.M., L.H. Applegate, P.M. Bergthold, S. Gallizioli, and S.C. Martin. 1980. Arizona range reference areas. USDA Forest Service Gen. Tech. Rep. RM-79. Rocky Mt. Forest and Range Exp. Sta., Fort Collins, Colo.

Webster, W.D., and J.K. Jones, Jr. 1982. Reithrodontomys megalotis. Mammalian species, No. 167, Amer. Soc. Mammal.

Wiens, J.A. 1973. Pattern and process in grassland bird communities. Ecol. Monogr. 43:237-270. 